\title{
FUNGSI MANAJEMEN KEPALA SEKOLAH, MOTIVASI, DAN KINERJA GURU
}

\author{
Rita Lisnawati \\ Program Studi Manajemen Pendidikan, Universitas Negeri Surabaya \\ Email : thalizrita5104@gmail.com
}

\begin{abstract}
Abstrak
Dalam dunia pendidikan saat ini banyak sekali persaingan. Output yang dihasilkan oleh sekolah harus sesuai dengan tujuan pendidikan nasional. Kepala sekolah sebagai manajer berperan penting dalam mewujudkan tujuan tersebut. Selain itu guru juga diharapkan tidak hanya mentransfer ilmu saja namun mampu memberikan kinerja dengan maksimal. Agar guru tersebut bisa mencapai kinerja yang maksimal maka harus didorongoleh motivasi yang tinggi. Penelitian ini bertujuan untuk mengetahui bagaimana tingkat fungsi manajemen kepala sekolah, motivasi guru, dan kinerja guru serta seberapa besar pengaruh motivasi guru terhadap kinerja guru.Teknik pengumpulan data menggunakan kuesioner (angket) yang desebarkan pada responden, observasi, wawancara, dan dokumentasi. Respon yang diukur melalui kuesioner disesuaikan dengan 4 skala likert. Uji validitas menggunakan Pearson Product Moment. Teknik analisis yang digunakan untuk menjawab pertanyaan penelitian menggunakan analisis statistik deskriptif, sedangkan untuk menjawab hipotesis penelitian terkait motivasi guru dan kinerja guru menggunakan Analisis Infernsial Regresi Linier Sederhana. Hasil penelitian menunjukkan bahwa : 1) Tingkat fungsi manajemen kepala sekolah berada pada kategori tinggi dengan nilai rata-rata jawaban responden sebesar 72,92. 2) Tingkat motivasi guru secara inferensial termasuk kategori tinggi dengan rata-rata skor $60<\mu \leq$ 80. 3) Tingkat kinerja guru secara inferensial termasuk kategori tinggi dengan rata-rata skor $60<\mu \leq 80.4$ ) Motivasi guru berpengaruh terhadap kinerja guru dengan koefisien determinasi model regresi linier sebesar $68,82 \%$.
\end{abstract}

Kata Kunci: Fungsi Manajemen Kepala Sekolah, Motivasi Guru, Kinerja Guru.

\begin{abstract}
Nowadays, there are many competitions in the world of education. Output which is generated by school should be in accordance with national education goals. Principal as the manager plays an important role in creating the goals. In addition, teachers are also expected not only to transfer knowledge but also to provide the maximum performance. In order to make teachers achieve maximum performance, they must be driven by high motivation. This research aims to find out how is the function level of principal management, motivation and performance of teacher and how big is the influence of teacher motivation on teacher performance.The technique of data collection is using a questionnaire which is spread to respondents, observations, interviews, and documentation. Responses were measured by questionnaire is adapted to 4 Likert scale. The test of validity is using Pearson Product Moment. The analysis technique which is used to answer the research questions is using the descriptive statistical analysis, while to answer the research hypothesis related to the motivation of teachers and teacher performance is using Simple Linear Regression Inferential Analysis. The results showed that: 1) The level of function of principal management is in high category with an average value of respondents amounted to 72.92. 2) The level of teacher motivation inferentially is in high category with an average score of $60<\mu \leq 80$. 3) The level of teacher performance inferentially is in high category with an average score of $60<\mu \leq 80$. 4) The motivation of teachers affects the performance of teachers with determination coefficient of linear regression models by $68.82 \%$.
\end{abstract}

Keywords: Principal Managerial Competence, Teacher Motivation, Teacher Performance.

\section{PENDAHULUAN}

Manajemen merupakan hal yang sangat penting dalam semua bidang kehidupan. Dengan manajemen, kinerja sebuah organisasi dapat berjalan secara maksimal. Demikian juga dengan lembaga pendidikan. Dengan manajemen yang baik, maka sebuah institusi pendidikan akan dapat berkembang secara optimal sesuai harapan.

Manajemen pendidikan di Indonesia merupakan titik sentral dalam mewujudkan tujuan pembangunan Sumber Daya Manusia (SDM). Dalam pengamatannya, manajemen pendidikan di Indonesia masih belum 
menampakkan kemampuan profesional sebagaimana yang diinginkan. Masalah manajemen pendidikan merupakan salah satu masalah pokok yang menimbulkan krisis dalam dunia pendidikan Indonesia. Kondisi ini disebabkan karena kurangnya tenaga-tenaga administrator pendidikan yang profesional.

Oleh karena itu, hal penting yang harus dipertimbangkan bagi sebuah institusi pendidikan adalah adanya tenaga administrator pendidikan yang profesional. Dalam pengelolaan administrasi pendidikan, diperlukan kualitas personil yang memadai, dalam arti penempatan orang yang tepat sesuai dengan fungsi yang diperlukan untuk kinerja yang efektif dan efisien.

Seiring dengan diberlakukannya otonomi daerah, maka telah terjadi perubahan paradigma dalam pengelolaan pendidikan yang antara lain telah memunculkan suatu model dalam manajemen pendidikan, yaitu school based management. Model manajemen ini pada dasarnya memberikan peluang yang sangat besar kepada sekolah untuk mengelola dirinya sesuai dengan kondisi yang ada serta memberikan kesempatan kepada masyarakat (stakeholders) untuk ikut berpartisipasi aktif dalam penyelenggaraan pendidikan. Konsekuensi dari pelaksanaan manajemen berbasis sekolah dalam setiap satuan, jenis, dan jenjang pendidikan antara lain sangat diperlukan adanya kemampuan manajerial yang cukup memadai dari kepala sekolah dan didukung oleh adanya kinerja guru yang profesional.

Keberhasilan pendidikan di sekolah sangat ditentukan oleh keberhasilan kepala sekolah dalam mengelola tenaga kependidikan yang tersedia di sekolah. Kepala sekolah bertanggung jawab atas penyelenggaraan kegiatan pendidikan, administrasi sekolah, pembinaan tenaga kependidikan lainnya, dan pendayagunaan serta pemeliharaan sarana dan prasarana. Hal tersebut menjadi lebih penting sejalan dengan semakin kompleksnya tuntutan tugas kepala sekolah, yang menghendaki dukungan kinerja yang semakin efektif dan efisien.

Kepala sekolah sebagai pimpinan tertinggi yang sangat berpengaruh dan menentukan kemajuan sekolah harus memiliki kemampuan administrasi, memiliki komitmen tinggi dan luwes dalam melaksanakan tugasnya. Dalam perannya sebagai seorang pemimpin, kepala sekolah harus dapat memperhatikan kebutuhan dan perasaan orang-orang yang bekerja dengan selalu memberikan motivasi kepada bawahannya sehingga kinerja guru selalu terjaga.

Dalam Peraturan Pemerintah No. 38 Tahun 1992 pasal 3 ayat 3 tentang Tenaga Pendidikan dijelaskan bahwa pengelola satuan pendidikan terdiri atas kepala sekolah, direktur, ketua, rektor dan pimpinan satuan pendidikan luar sekolah. Kepala sekolah sebagai salah satu pengelola satuan pendidikan juga disebut sebagai administrator, dan disebut juga sebagai manajer pendidikan. Tinggi rendahnya kinerja sebuah organisasi ditentukan oleh sang manajer. Kepala sekolah sebagai manajer merupakan pemegang kunci maju mundurnya sekolah. Hal ini sejalan dengan pendapat (Richardson \& Barbe 1986) yang menyatakan, "principals is perhaps the most significant single factor in establishing an effective school" (Kepala Sekolah merupakan faktor yang paling penting didalam membentuk sebuah sekolah yang efektif).

Manajemen atau pengelolaan dapat berarti macammacam tergantung kepada siapa yang membicarakannya. Istilah manajemen sendiri berasal dari "manage" yang padanan dalam bahasa Indoensia adalah kelola. Pengertian umum dari manajemen adalah proses mencapai hasil dengan mendayagunakan sumber daya yang tersedia secara produktif (Depdiknas 2007).

Manajemen pendidikan dimaknai sebagai aktifitas memadukan sumber-sumber pendidikan agar terpusat dalam mencapai tujuan pendidikan yang telah ditentukan (Pidarta 2004). Yang dimaksud dengan sumber-sumber daya pendidikan disini adalah ketenagaan, dana, sarana dan prasarana termasuk informasi. Dengan demikian maka kemampuan seorang manajer dalam menjalankan tugas menejerial adalah memadukan sumber daya tersebut. Dalam definisi ini tentu saja meliputi proses perencanaan, pengorganisasian, penggerakan, dan pengendalian sebagai fungsi manajemen (Sudibyo 2008). Bagaimana sumberdaya direncanakan, diorganisasikan, diarahkan, dan dikendalikan dalam upaya mencapai tujuan organisasi inilah pertanyaan yang harus dijawab dalam tugas manajerial.

Sedangkan Richard (Pidarta 2004) mendefinisikan manajemen pendidikan sebagai upaya seseorang untuk mengarahkan, dan memberi kesempatan kepada orang lain untuk melaksanakan pekerjaan secara efektif, dan menerima pertanggungjawaban pribadi untuk mencapai pengukuran hasil yang ditetapkan. Dalam konteks ini lebih ditekankan pada pencapaian fungsi-fungsi manajemen dan hasil yang dapat diukur dengan jelas. Oleh karena itu tujuan harus dirumuskan dengan jelas dalam suatu ukuran yang dapat dihitung sehingga jelas perbandingannya antara perencanaan dengan hasil yang dicapai atas dasar perencanaan. Dengan kata lain manajemen membutuhkan suatu standar sebagai ukuran keberhasilan.

Manajer adalah seorang yang berusaha untuk mencapai maksud-maksud yang dapat dihitung, dan administrator sebagai orang yang berikhtiar untuk maksud-maksud yang tidak dapat dihitung tanpa mengindahkan akibat-akibat akhir dari pencapaiannya (Sutrisno 1985).

(Tendik 2008) menyatakan bahwa fungsi manajemen ini harus dipahami secara lebih luas, misalnya dalam 
perencanaan seorang kepala sekolah harus menguasai teori perencanaan dan seluruh kebijakan pendidikan nasional sebagai landasan dalam perencanaan sekolah, baik perencanaan yang strategis, perencanaan yang operasional, perencanaan tahunan, perencanaan kebutuhan dan anggaran sekolah. Penyusunan perencanaan ini juga meliputi perencanaan operasional, perencanaan strategis dengan memegang teguh prinsip perencanaan yang baik.

Dalam hal pengembangan organisasi juga dikatakan bahwa kepala sekolah harus menguasai teori dan seluruh kebijakan pendidikan nasional dalam mengembangkan organisasi sekolah, prinsip efisiensi dan efektifitas pengembangan harus diutamakan.

(Susanto 2008) menyebutkan bahwa manajerial yang sukses menampakkan hal berikut : (1) Manajemen harus mampu mengkritisi diri sendiri, mampu mengakui, menerima, serta belajar dari kesalahan masa lalu, (2) Mendorong konfrontasi yang terbuka maupun konstruktif dan dipandang sebagai sebuah metode pemecahan masalah (3) Keputusan dengan konsensus, keputusan bersama yang dibuat harus didukung sepenuhnya, posisi dalam organisasi tidak menjamin kualitas ide (4) Manajemen yang terbuka dan berlaku sesuai dengan etika dengan mengatakan hal yang sebenarnya dan memberikan perlakuan yang sama bagi setiap karyawannya (5) Percaya pada prinsip kerja keras, dimana produktifitas yang tinggi adalah sesuatu yang dibanggakan, memiliki komitmen jangka panjang, jika terjadi masalah dengan karir pengunduran diri lebih baik daripada pemberhentian.

Berdasarkan uraian di atas maka dalam penelitian ini yang dimaksud dengan fungsi manajemen adalah suatu elemen yang melekat dan selalu ada dalam kegiatan proses menajamen yang dijadikan sebagai suatu acuan oleh seorang manajer pada waktu melaksanakan suatu kegiatan guna mencapai suatu tujuan tertentu.

Dengan kemampuan profesional manajemen pendidikan, kepala sekolah diharapkan dapat menyusun program sekolah yang efektif, menciptakan iklim sekolah yang kondusif dan membangun unjuk kerja personel sekolah serta dapat membimbing guru melaksanakan proses pembelajaran. Di sekolah, kepala sekolah senantiasa berinteraksi dengan guru bawahannya, memonitor dan menilai kegiatan mereka sehari-hari. Rendahnya kinerja guru akan berpengaruh terhadap pelaksanaan tugas yang pada gilirannya akan berpengaruh pula terhadap pencapaian tujuan pendidikan. Rendahnya kinerja guru harus diidentifikasi penyebabnya.

Peranan kepala sekolah dalam rangka meningkatkan mutu pendidikan sangat penting karena dapat mempengaruhi berhasil dan tidaknya mutu pendidikan itu sendiri. Kepala sekolah sebagai tulang punggung mutu pendidikan dituntut untuk bertindak sebagai pembangkit semangat, mendorong, merintis dan memantapkan serta sekaligus sebagai administrator. Dengan perkataan lain bahwa kepala sekolah adalah salah satu penggerak pelaksanaan manajemen pendidikan yang berkualitas.

Banyak variabel yang mempengaruhi kinerja guru di antaranya adalah motivasi kerja guru. Motivasi kerja guru merupakan sesuatu yang sangat penting, karena dapat menunjang kelancaran pelaksanaan tugas sebagai pendidik yang pada akhirnya berpengaruh terhadap kinerja guru itu sendiri. Oleh sebab itu pimpinan harus senantiasa berupaya meningkatkan motivasi kerja guru serta harus memiliki kemampuan di dalam memahami berbagai aspek yang berkaitan dengan motivasi, terutama memahami kebutuhan yang dimanifestasikan melalui perilaku guru dalam melaksanakan tugas. Perilaku guru muncul karena adanya interaksi secara vertikal dan horizontal antara pimpinan dengan bawahan dan antara bawahan dengan bawahan. Dengan demikian tinggi rendahnya motivasi kerja yang dimiliki oleh guru kemungkinan berpengaruh terhadap kinerja guru.

(Wahjusumidjo 1999) mengemukakan pengertian motivasi sebagai konsep manejemen dalam kaitannya dengan kehidupan sekolah dan kepemimpinan, adalah sebagai berikut : Motivasi adalah dorongan kerja yang timbul pada diri sendiri untuk berperilaku dalam mencapai tujuan yang telah ditentukan. Motivasi merupakan kekuatan pendorong yang akan mewujudkan suatu perilaku guna mencapai tujuan peningkatan prestasi kerja dirinya.

Motivasi kerja guru merupakan sesuatu yang sangat penting, karena dapat menunjang kelancaran pelaksanaan tugas sebagai pendidik yang pada akhirnya berpengaruh terhadap kinerja guru itu sendiri. Oleh sebab itu pimpinan harus senantiasa berupaya meningkatkan motivasi kerja guru serta harus memiliki kemampuan di dalam memahami berbagai aspek yang berkaitan dengan motivasi, terutama memahami kebutuhan yang dimanifestasikan melalui perilaku guru dalam melaksanakan tugas. Perilaku guru muncul karena adanya interaksi secara vertikal dan horizontal antara pimpinan dengan bawahan dan antara bawahan dengan bawahan. Dengan demikian tinggi rendahnya motivasi kerja yang dimiliki oleh guru kemungkinan berpengaruh terhadap kinerja guru.

Motivasi mempengaruhi jenis penyesuaian yang dilakukan oleh para guru terhadap sekolah. Produktivitas dipengaruhi oleh motif-motif khusus yang dimiliki oleh para guru dalam hal bekerja di sekolah, dan dalam hal melaksanakan tugas-tugas sebagai guru. Dalam banyak hal, tugas kepala sekolah adalah menyalurkan motif-motif para guru secara efektif ke arah tujuan-tujuan sekolah.

Menurut Henry Simamora (Mangkunegara 2007) menyatakan bahwa terdapat hubungan antara motivasi kerja terhadap kinerja. Faktor yang mempengaruhi kinerja 
guru di antaranya yaitu motivasi kerja guru. Hal ini terlihat dari pernyataan Henry Simamora mengenai faktor-faktor yang mempengaruhi kinerja, di antaranya faktor psikologis, dalam faktor ini terdapat variabel motivasi kerja terhadap pekerjaannya sendiri. Berdasarkan dari pernyataan di atas bahwa terdapat hubungan antara motivasi kerja guru terhadap kinerja guru.

Berdasarkan kajian teoritis sebagaimana terdeskripsi di atas, ada beberapa alasan yang mendorong penulis untuk melakukan penelitian ini. Pertama, kemajuan di bidang pendidikan membutuhkan manajer pendidikan yang mampu mengelola satuan pendidikan dan mampu meningkatkan kinerja guru dalam mencapai tujuan pendidikan. Kedua, persepsi masyarakat selama ini memposisikan guru sebagai kunci utama keberhasilan atau kegagalan pendidikan. Ketiga, pandangan masyarakat yang menilai Yayasan As-Syifa Al-Khoeriyyah Subang adalah yayasan yang bagus. Keempat, kajian empiris dengan tema ini menarik untuk dilakukan mengingat perkembangan ilmu dan teori manajemen, khususnya manajemen pendidikan, yang berjalan dengan pesat. Untuk membuktikan secara ilmiah yang didukung oleh data yang empiris terkait fenomena yang telah dipaparkan di atas, maka dipandang perlu mengadakan penelitian terkait fungsi manajemen kepala sekolah, motivasi, dan kinerja guru di Yayasan As-Syifa Al-Khoeriyyah Subang.

Pertanyaan penelitiannya adalah sebagai berikut : (1) Bagaimana fungsi manajemen kepala sekolah di Yayasan As-Syifa Al-Khoeriyyah Subang? (2) Bagaimana motivasi guru di Yayasan As-Syifa Al-Khoeriyyah Subang? (3) Bagaimana kinerja guru di Yayasan As-Syifa AlKhoeriyyah Subang? (4) Apakah terdapat pengaruh motivasi guru terhadap kinerja guru di Yayasan As-Syifa Al-Khoeriyyah Subang?

Berdasarkan latar belakang, kajian teori, dan kajian penelitian yang relevan, maka dilakukan penelitian dengan judul Fungsi Manajemen Kepala Sekolah, Motivasi, dan Kinerja Guru di Yayasan As-Syifa AlKhoeriyyah Subang dengan tujuan untuk mendeskripsikan dan menganalisis: fungsi manajemen kepala sekolah di Yayasan As-Syifa Al-Khoeriyyah Subang, motivasi guru di Yayasan As-Syifa Al-Khoeriyyah Subang, kinerja guru di Yayasan As-Syifa Al-Khoeriyyah Subang, dan pengaruh motivasi guru terhadap kinerja guru di Yayasan As-Syifa Al-Khoeriyyah Subang.

\section{METODE}

Pada penelitian ini penulis menggunakan pendekatan penelitian kuantitatif. Jenis penelitiannya adalah penelitian deskriptif kuantitatif dan korelasional. Jenis penelitian deskriptif dalam penelitian ini digunakan untuk mendeskripsikan fungsi manajemen kepala sekolah, motivasi guru, dan kinerja guru di Yayasan As-Syifa Al-
Khoeriyyah Subang, sedangkan jenis penelitian korelasional untuk menyatakan adanya pengaruh positif motivasi guru terhadap kinerja guru yang diuji dengan menggunakan regresi linier sederhana.Pada dasarnya bagian ini menjelaskan bagaimana penelitian itu dilakukan.

Populasi dalam penelitian ini adalah seluruh guru dan kepala sekolah di Yayasan As-Syifa Al-Khoeriyyah Subang yang berjumlah 144 orang, yaitu terdiri dari 3 orang kepala sekolah, 7 orang guru TK, 70 orang guru SMP, dan 64 orang guru SMA. Sedangkan untuk sampel peneliti mengambil sampel dari populasi sebesar $25 \%$, jadi banyaknya sampel adalah $25 \% \times 144=36$ orang guru. Sedangkan untuk kepala sekolah diambil keseluruhannya yaitu 3 orang.

Teknik pengumpulan data yaitu menggunakan angket (kuesioner), observasi, wawancara, dan dokumentasi. Teknik analisis datanya menggunakan analisis deskriptif, uji mean satu populasi, dan regresi linier sederhana.

Instrumen penelitian digunakan untuk mengukur variabel yang akan diteliti, dengan demikian jumlah instrumen yang akan digunakan untuk penelitian akan tergantung pada jumlah variabel yang diteliti. Dalam penelitian ini terdapat tiga variabel, maka instrumennya sebagai berikut : (1) Instrumen yang digunakan untuk mengukur variabel fungsi manajemen kepala sekolah di Yayasan Asyifa Al-Khoeriyyah Subang sumber datanya adalah kepala sekolah. Bentuk instrumennya adalah daftar checlist. Untuk itu dapat digunakan sebagai pedoman observasi, wawancara, maupun sebagai angket.(2) Instrumen yang digunakan untuk mengukur variabel motivasi guru di Yayasan Asyifa Al-Khoeriyyah Subang sumber datanya adalah guru. Bentuk instrumennya berupa angket.(3) Instrumen yang digunakan untuk mengukur variabel kinerja guru di Yayasan Asyifa Al-Khoeriyyah Subang sumber datanya adalah kepala sekolah. Bentuk instrumennya adalah daftar checlist. Untuk itu dapat digunakan sebagai pedoman observasi, wawancara, maupun sebagai angket.

\section{HASIL DAN PEMBAHASAN}

Untuk variabel fungsi manajemen kepala sekolah, motivasi guru, dan kinerja guru dibuat 5 kategorisasi yaitu sangat tinggi, tinggi, sedang, rendah, dan sangat rendah dengan kriteria sebagai berikut :

Tabel 1. Skala 0-100

\begin{tabular}{ccc}
\hline No. & Skala & Keterangan \\
\hline 1 & $0<\mu \leqslant 20$ & Sangat Rendah \\
2 & $20<\mu \leqslant 40$ & Rendah \\
3 & $40<\mu \leqslant 60$ & Sedang \\
4 & $60<\mu \leqslant 80$ & Tinggi \\
5 & $80<\mu \leqslant 100$ & Sangat Tinggi
\end{tabular}




\section{Fungsi Manajemen Kepala Sekolah}

Variabel fungsi manajemen kepala sekolah dalam penelitian ini disusun berdasarkan empat dimensi, yaitu fungsi perencana (5 indikator), fungsi pemimpin (4 indikator), fungsi mengelola dan mengembangkan sumber daya (5 indikator), dan fungsi monitoring, evaluasi, dan pelaporan ( 2 indikator). Berikut ini adalah ringkasan data mengenai rata-rata (mean) setiap dimensi pada variabel fungsi manajemen kepala sekolah.

Tabel 2. Fungsi Manajemen Kepala Sekolah

\begin{tabular}{clc}
\hline No. & \multicolumn{1}{c}{ Dimensi } & Rata-rata \\
\hline 1 & Fungsi Perencana & 68.89 \\
2 & Fungsi Pemimpin & 66,67 \\
3 & $\begin{array}{l}\text { Fungsi Mengelola dan Mengembangkan Sumber } \\
\text { Daya }\end{array}$ & 77,78 \\
& Fungsi Monitoring, Evaluasi, dan Pelaporan & 83,33 \\
\hline \multirow{2}{*}{ Total Rata-rata } & $\mathbf{7 2 , 9 2}$ \\
\hline
\end{tabular}

Tabel di atas menjelaskan bahwa skor jawaban data yang diperoleh dari 3 orang responden memiliki rata-rata berbeda-beda untuk setiap dimensi. Meski demikian semua indikator pada masing-masing dimensi menunjukkan rata-rata skor jawaban di atas 60 dengan interpretasi kategori jawaban dengan kategori tinggi, sehingga fungsi manajemen kepala sekolah di Yayasan As-Syifa Al-Khoeriyyah Subang sudah memenuhi kriteria baik.

Hal ini sejalan dengan pendapatnya George R. Terry (Sutopo 1999) yang menyatakan bahwa fungsi manajemen mencakup kegiatan-kegiatan perencanaan, pengorganisasian, penggerakkan, dan pengawasan yang dilakukan untuk mencapai sasaran yang telah ditetapkan melalui pemanfaatan sumber daya manusia dan sumber daya lainnya. Hal ini juga sesuai dengan penelitian yang dilakukan oleh (Hadi 2010) yang menggunakan empat dimensi fungsi manajemen kepala sekolah.

\section{Motivasi Guru}

\begin{tabular}{clc}
\multicolumn{3}{c}{ Tabel 3. Motivasi Guru } \\
\hline No. & \multicolumn{1}{c}{ Dimensi } & Rata-rata \\
\hline 1 & Kebutuhan Fisiologis & 81,67 \\
2 & Kebutuhan Rasa Aman & 87,04 \\
3 & Kebutuhan Sosial & 72,22 \\
4 & Kebutuhan Penghargaan & 79,63 \\
5 & Kebutuhan Aktualisasi Diri & 61,11 \\
\hline & \multicolumn{2}{c}{ Total Rata-rata } \\
\hline
\end{tabular}

Dari data yang diperoleh tiap dimensi dari motivasi guru, dapat diketahui bahwa skor nilai rata-rata berurutan dari kebutuhan fisiologis, kebutuhan rasa aman, kebutuhna sosial, kebutuhan penghargaan, dan kebutuhan aktualisasi diri adalah 81,$67 ; 87,04 ; 72,22 ; 79,63$; dan 61,11. Dari nilai rata-rata kebutuhan fisiologis, kebutuhan rasa aman, kebutuhan sosial, kebutuhan penghargaan, dan kebutuhan aktualisasi diri tergolong pada kategori tinggi.

Dalam hal ini penulis menemukan kesamaan dalam hal fakor-faktor motivasi dengan penelitian yang dilakukan oleh (Mauliyah 2010) terkait kebutuhan fisiologis, kebutuhan aka rasa aman, kebutuhan sosial, kebutuhan akan penghargaan, dan kebutuhan aktualisasi diri. Selain itu, penelitian ini juga sejalan dengan teori Abraham Maslow (As'ad 1998) yang terkenal dengan sebutan hierarki kebutuhan.

\section{Kinerja Guru}

\begin{tabular}{|c|c|c|}
\hline No. & Dimensi & Rata-rata \\
\hline 1 & Merencanakan Program Belajar Mengajar & 68,83 \\
\hline 2 & $\begin{array}{l}\text { Melaksanakan dan Memimpin Proses Belajar } \\
\text { Mengajar }\end{array}$ & 66,15 \\
\hline 3 & Menilai Kemajuan Proses Belajar Mengajar & 61,23 \\
\hline 4 & Membina Hubungan dengan Peserta Didik & 67,18 \\
\hline \multicolumn{2}{|r|}{ Total Rata-rata } & 72,92 \\
\hline
\end{tabular}

Dari data yang diperoleh tiap dimensi dari kinerja guru, dapat diketahui bahwa skor nilai rata-rata berurutan dari merencanakan program belajar mengajar, melaksanakan dan memimpin proses belajar mengajar, menilai kemajuan proses belajar mengajar, dan membina hubungan dengan peserta didik adalah 68,83 ; 66,15 ; 61,23 ; dan 67,18. Dari nilai rata-rata merencanakan program belajar mengajar, melaksanakan dan memimpin proses belajar mengajar, menilai kemajuan proses belajar mengajar, dan membina hubungan dengan peserta didik tergolong pada kategori tinggi.

Hal ini sejalan dengan pendapat (Sudijarto 1993) yang menyatakan bahwa kemampuan yang harus dikuasai oleh seorang guru yaitu merencanakan program belajar mengajar, melaksanakan dan memimpin proses belajar mengajar, menilai kemajuan proses belajar mengajar, dan membina hubungan dengan peserta didik. Penulis juga menemukan bahwasannya hal tersebut releva dengan penelitian yang dilakukan oleh (Muslihuddin 2007) terkait dimensi-dimensi dalam menilai kinerja.

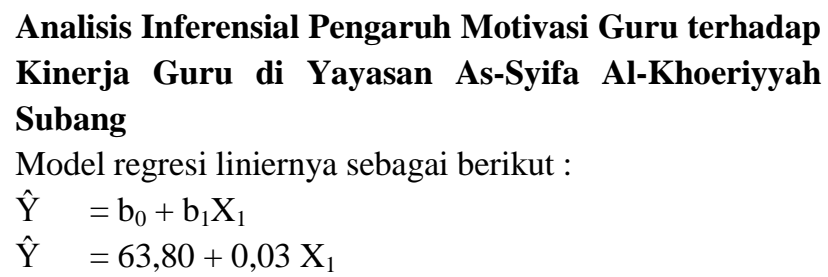


Untuk mengetahui ada atau tidaknya hubungan linear antara motivasi guru dengan kinerja guru dilakukan pengujian dengan langkah-langkah sebagai berikut :

- $\mathrm{H}_{0}$ : ada hubungan linier antara motivasi guru dengan kinerja guru $*$

- $\mathrm{H}_{1}$ : tidak ada hubungan linier antara motivasi guru dengan kinerja guru

- $\alpha=0,05$

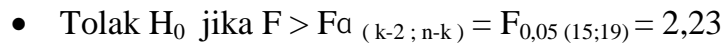
dengan $\mathrm{F}=((\mathrm{SSE}-\mathrm{SSPE}) /(\mathrm{k}-2)) /(\mathrm{SSPE} /((\mathrm{n}-\mathrm{k})))$

- Menghitung nilai statistik F : $\mathrm{F}=((1361,14-645,73) /(17-2)) /(645,73 /((36-17)))=1,403$

- Kesimpulan

Karena $\mathrm{F}=1,403<2,23$, maka $\mathrm{H}_{0}$ diterima sehingga klaim diterima. Artinya cukup alasan untuk menyatakan bahwa terdapat hubungan linear antara motivasi guru dengan kinerja guru.

Tabel 5. ANAVA

\begin{tabular}{ccccc}
\hline Sumber Variansi & Sum Square & Db & Mean Square & F $_{\text {hitung }}$ \\
\cline { 1 - 4 } Regresi & 3004,144 & 1 & 3004,144 & \\
Error & 1361,136 & 34 & 40,033 & \multirow{2}{*}{75,04} \\
\cline { 1 - 4 } Total & 4365,28 & 35 & & \\
\hline
\end{tabular}

Untuk $a=0,05$ dengan $\mathrm{F}_{\mathrm{a}(1 ; 34)}=4,13$.

Karena $F_{\text {hitung }}=75,04>4,13$, maka ada pengaruh signifikan motivasi guru terhadap kinerja guru.

Selanjutnya koefisien determinasi regresi linier adalah :

$\mathrm{r}_{\mathrm{xy}}{ }^{2}=\mathrm{SSR} / \mathrm{SST}=3004,144 / 4365,28=0,6882=68,82 \%$

Ini berarti 68,82 varians kinerja guru terjelaskan oleh varians motivasi guru.

Dari hasil penelitian ini sesuai dengan penelitian sebelumnya (Mauliyah 2010), bahwa faktor-faktor motivasi yang meliputi kebutuhan fisiologis, kebutuhan keamanan dan keselamatan kerja, kebutuhan sosial kebutuhan penghargaan, dan kebutuhan aktualisasi diri berpengaruh terhadap peningkatan kinerja.

Hasil tersebut sesuai dengan pendapat (Hasibuan 2001) yang mendefinisikan motivasi sebagai suatu perangsang (want) dan daya penggerak kemauan bekerja seseorang. Sementara dikatakan oleh (Siagian 2007) bahwa motivasi adalah daya pendorong yang mengakibatkan seorang anggota organisasi mau dan rela untuk menggerakkan kemampuan dalam bentuk keahlian dan keterampilan, tenaga, dan waktunya untuk menyelenggarakan berbagai kegiatan yang menjadi tanggungjawabnya dan memfungsikan kewajibannya dalam rangka untuk mencapai tujuan dan berbagai sasaran organisasi yang elah ditentukan sebelumnya. Selain itu, Gordon W yang dikutip (Mangkunegara 2007) juga menyatakan bahwa ada hubungan yang positif antara motivasi berprestasi dengan pencapaian kinerja.

\section{PENUTUP}

\section{Simpulan}

Berdasarkan hasil penelitian,berikut ini akan disajikan simpulan dari temuan mengenai Fungsi Manajemen Kepala Sekolah, Motivasi, dan Kinerja Guru di Yayasan As-Syifa Al-Khoeriyyah Subang yaitu sebagai berikut: (1) Tingkat fungsi manajemen kepala sekolah di Yayasan AsSyifa Al-Khoeriyyah Subang tergolong kualifikasi yang tinggi, karena kepala sekolah sudah mampu membuat perencanaan, pengorganisasian, pengelolaan, dan pengawasan dengan baik. (2) Tingkat motivasi guru di Yayasan As-Syifa Al-Khoeriyyah Subang termasuk kualifikasi yang tinggi, karena kebutuhan fisiologis, sosial, aktualisasi diri, penghargaan, dan rasa aman guru sudah terpenuhi degan baik sehingga motivasi guru juga meningkat. (3) Tingkat kinerja guru di Yayasan As-Syifa Al-Khoeriyyah Subang termasuk kualifikasi yang tinggi, karena pembelajaran di sekolah telah berjalan dengan efektif dan hal-hal terkait administrasi sekolah juga sudah dipenuhi guru sesuai dengan tugasnya masing-masing. (4) Motivasi guru berpengaruh positif secara signifikan terhadap kinerja guru di Yayasan As-Syifa Al-Khoeriyyah Subang, karena semakin tinggi motivasi guru yang diberikan oleh kepala sekolah terhadap guru maka dapat meningkatkan kinerja guru. Begitu pula sebaliknya, semakin menurun motivasi guru maka semakin rendah pula kinerja guru, sehingga akan berdampak pada sekolah dengan terwujudnya visi, misi, dan tujuan sekolah tersebut.

\section{Saran}

Berdasarkan temuan dalam penelitian ini, dapat disarankan beberapa hal sebagai berikut: (1) Untuk meningkatkan fungsi manajemen kepala sekolah di Yayasan As-Syifa Al-Khoeriyyah Subang supaya lebih tinggi yaitu kepala sekolah harus membuat assesmen terkait kebutuhan-kebutuhan di sekolah yang dipimpinnya.(2) Untuk meningkatkan motivasi guru di Yayasan As-Syifa Al-Khoeriyyah Subang supaya lebih tinggi lagi yaitu dengan cara memberikan motivasi tambahan selain memenuhi kebutuhan-kebutuhan dasar yang dibutuhkan oleh guru, seperti memberikan insentif, promosi jabatan, dan sebagainya.(3) Untuk lebih meningkatkan kinerja guru di Yayasan As-Syifa AlKhoeriyyah Subang supaya lebih tinggi lagi yaitu dengan cara memberikan pelatihan-pelatihan atau workshop untuk guru terkait kompetensi-kompetensi yang harus dimiliki oleh seorang guru. Selain itu kepala sekolah juga bisa memberikan hukuman (punishment) untuk guru yang belum maksimal melaksanakan tugasnya di sekolah. 


\section{DAFTAR PUSTAKA}

As'ad, M., 1998. Psikologi Industri, Yogyakarta: LIberty.

Depdiknas, 2007. Standar Isi untuk Satuan Pendidikan Dasar dan Menengah, Jakarta: Dirjen Dikti Depdiknas.

Hadi, S., 2010. Pengaruh Keterampilan Manajer Kepala Sekolah dalam Hubungan Kemanusiaan dan Motivator Terhadap Kinerja Guru SDN di Kabupaten Lamongan. Universitas Negeri Surabaya.

Hasibuan, M., 2001. Manajemen Sumber Daya Manusia, Jakarta: Bumi Aksara.

Mangkunegara, A.P., 2007. Manajemen Sumber Daya Manusia, Cetakan ke tujuh, Bandung: PT Remaja Rosdakarya.

Mauliyah, A., 2010. Pengaruh Gaya Kepemimpinan Kepala Sekolah dan Motivasi Terhadap Kinerja Guru di Yayasan Buana Wedoro Waru Sidoarjo. Universitas Negeri Surabaya.

Muslihuddin, 2007. Pengaruh Kemampuan Manajer Kepala Sekolah dan Kemampuan Supervisi Terhadap Kinerja Guru SMP Negeri di Kota Selong Kabupaten Lombok Timur. Universitas Negeri Surabaya.

Pidarta, M., 2004. Manajemen Pendidikan Indonesia, Jakarta: Rineka Cipta.

Richardson \& Barbe, 1986. Principals is Perhaps the Most Significant Single Factor in Establishing an effective School, Retrieved from http://bankilmu540.blogsport.com.

Siagian, S., 2007. Teori Motivasi dan Aplikasinya, Jakarta: PT Rineka Cipta.

Sudibyo, A., 2008. Manajemen dan Fungsi-fungsinya, Bandung: Pustaka Setia.

Sudijarto, 1993. Menuju Pendidikan Nasional yang Relevan dan Bermutu, Jakarta: Balai Pustaka.

Susanto, A., 2008. Sistem Informasi Manajemen, Bandung: Lingga Jaya.

Sutopo, H.B., 1999. Metode Penelitian Kualitatif, Surakarta: UNS Press.

Sutrisno, H., 1985. Metodologi Research Jilid I dan II, Yogyakarta: Graha Ilmu.

Tendik, D., 2008. Langkah-Langkah PTS, Bandung: PT. Gunung Agung.

Wahjusumidjo, 1999. Kepemimpinan Kepala Sekolah, Jakarta: Raja Grafindo Persada. 